\title{
Margaret Cavendish, the Antwerp Carmel and The Convent of Pleasure
}

\author{
J.P. Vander Motten and Katrien Daemen-de Gelder
}

Preserved in the Antwerp city archives is a chronicle history, entitled 'Short Colections of the Beginings of Our English Monastery of Teresians in Antwerp with some few perticulars of our Dear Deceased Religious'. Commissioned by prioress Mary Frances of St Teresa (Mary Birkbeck, 1674-1733) and begun around 1730 by Mary Joseph of St Teresa (Mary Howard, 1688-1756), it comprises foundational documents as well as the lives of ninety-five nuns and lay sisters who professed in the English Carmelite convent in Antwerp between 1619 and 1721. ${ }^{1}$ These annals were put together for preservation and edification purposes, "that those present and those who shall follow may be animated with the Primitive Spirit and fervour courageously to follow the examples of these their predecessors." (unnumbered page). They commemorate the foundation of the Carmel in 1619 by Lady Mary Lovell (c.1564-1628) and Anne Worsley (1588-1644), Anne of the Ascension in religion, and throughout celebrate the nuns' fidelity to the reforms initiated by the Carmelite founder St Teresa de Jesus (1515-82). The book was taken to Rome in 1731 to be presented to the Reverend Father Thomas Percy Plowden (1672-1745), the convent's formal spiritual director and current rector of the English College in Rome, "that he might see it and how we hav[e] endeavour'd to put in execution what he so often and earnestly recommended to us ..."(ib.). Commenting favorably upon its progression and holding up the nuns' unblemished piety as a model for emulation, Father Plowden recommended that the chronicle be "read over once a year in the Refectory" (ib.). Drawing on a variety of materials, including personal reminiscences, nuns' testimonies, and printed materials, the Lives typically provide some basic facts about the subjects' family as well as an account of their lives of prayer, dedication and abstinence.

One of these, the Life of Mary Cotton (1629-94), Sister Mary of the Blessed Trinity, daughter of Edward Cotton and Mary Brett, concludes with the following statement: "when she [i.e. Mary] came to be Religious the Dutchess of New Castle being then here was much

\footnotetext{
${ }^{1}$ Felixarchief Antwerp, KK 1018 ('Engelse Theresianen, Kloosterkroniek'). For an annotated edition of the complete text, see English Convents in Exile, 1600-1800, gen. ed. Caroline Bowden. Part II, vol. 4 : Life Writing II (London, 2013), ed. Katrien Daemen-de Gelder. All in-text references will be to page numbers in Collections.
} 
taken with her as being extream pretty, entertaind her at her own house dressed her with her own hands for her Entery like a Nimph and lead her in her self" (509-15; 515). Although this is the only evidence we have connecting the Duchess of Newcastle with the Antwerp Carmelite community, there is no reason to doubt the accuracy of the chronology. Margaret and William Cavendish took up their residence in the Rubens House in September 1648. Except for Margaret's stay in England from November 1651 until February 1653, the couple remained in the city until the Restoration. ${ }^{2}$ Cotton was professed on 16 July 1656. (509) Frustratingly terse as it is, the entry adds to our knowledge of the Duchess's social and intellectual milieu during the Antwerp years. Indirectly it also raises a number of questions which, in the absence of further tangible evidence, we intend to answer in a tentative but hopefully plausible manner.

How Mary Cotton may have been introduced to the Cavendish circle at Antwerp must briefly be considered. There is no factual evidence available linking the Cavendishes with the Cottons, directly or indirectly. The company Margaret kept at Antwerp is known to have included such grandees as Don John of Austria, the prince of Condé, the duke of Oldenburg, as well as the Duarte family (see below) and others who visited her husband's manège. ${ }^{3}$ While providing an entertaining description of the local folk and their pastimes in CCXI Sociable Letters (1664), the Duchess in the Life of her husband (1667) also called the city "a place of great resort for Strangers and Travellers", where at the time of their "coming thither, we found but few English (except those that were Merchants) but afterwards their number increased much, especially of Persons of Quality" (64). ${ }^{4}$ Whoever these may have been, it is reasonable to suppose that some of them, exiles and expatriates as well as merchants, were welcomed into the Cavendish home. In Natures Pictures (1656), Margaret confessed that she was by nature given "to contemplation rather than conversation, to solitariness rather than

\footnotetext{
${ }^{2}$ Katie Whitaker, Mad Madge. Margaret Cavendish, Duchess of Newcastle, Royalist, Writer and Romantic (London, 2004), passim (hereafter Whitaker); James Fitzmaurice, 'Cavendish, Margaret, duchess of Newcastle upon Tyne (1623?-1673)', Oxford Dictionary of National Biography, Oxford University Press, 2004 [http://www.oxforddnb.com/view/article/4940].

${ }^{3}$ Whitaker, $172 \mathrm{ff}$.

${ }^{4}$ CCXI Sociable Letters, Written by the Thrice Noble, Illustrious, and Excellent Princess, The Lady Marchioness of Newcastle (London, 1664), 398-407; The Life of the Thrice Noble, High and Puissant Prince William Cavendishe. Written by the thrice Noble, Illustrious, and Excellent Princess, Margaret, Duchess of Newcastle, His Wife (London, 1667). On Margaret's literary use of this world, see James Fitzmaurice, "Margaret Cavendish in Antwerp: the Actual and the Imaginary", In-Between: Essays \& Studies in Literary Criticism, 9 (2000), 2939.
} 
society, to melancholy rather than mirth". 5 Despite this suggestion of reclusiveness, she was not unlike the "great Lady" in one of the prose dialogues in the same work, who claims: "I do not only keep one furnished table, but many, and do allow to entertain all civil Guests". Mary Cotton may have been one of those "entertained" by Cavendish "at her own house" after her arrival at Antwerp ("when she came to be Religious") and prior to her entry in the Carmel. Descended from the reputable Brett family of Somerset, Mary followed in the steps of four cousins who had preceded her there, Catherine (1619-78) and Anne Keynes (1628-96) ${ }^{6}$; and Ann (1624-78) and Mary Harcourt (1631-90). ${ }^{7}$ In accordance with the provisions in the Carmelite constitutions, Cotton would have gone through a novitiate (or probation) of at least one year before being professed, which implies that she had arrived in the city by July 1655 at the latest, and since she appears to have enjoyed the Duchess's hospitality, quite possibly sometime before then.

Recollections of her pre-convent days are contained in Mary Cotton's seven-page Life, which partly consists of her own account of her vocation. When she was "upon condition of making [her] election", she faced the moral conflict between the desire to become a nun and the "worldly allurements" (509) obstructing her final decision. In the abstract terminology characteristic of such memoirs, she recalled that "[o]ne of the chiefest and most powerfull" of these "allurements" was "a special fortune then present which in many respects did promise great temporall happiness and diverse exteriour apparances [sic] of a most absolute affection unto my self". The prospect of a life in a religious order did not match "the contentments which were to be found in worldly friendships...in the Society of those that professd me most intire affection". Cotton dreaded the idea of being "forever deprived of ye Company of those whose conversation had formerly been very delightfull unto me, in so much that it seemd my life consisted in remaining with them". In "a most unspeakable dejection of mind" (511) she finally turned to her confessor, who encouraged her "to forsake the pleasures of the world".

\footnotetext{
${ }^{5}$ Natures Pictures Drawn by Fancies Pencil To The Life. Written by the thrice Noble, Illustrious, and Excellent Princess, the Lady Marchioness of Newcastle (London, 1656), 385. Hereafter Natures Pictures.

${ }^{6}$ Catherine, Anne of the Ascension in religion, and Anne, or Anne of Jesus, were the daughters of Edward Keynes and Anne, daughter to Alexander Brett, described in the sisters' lives as "Knight Native of Somersetshire" $(358,436)$. Catherine was professed in November 1639 and chosen superior in 1650. It was during her term that Cotton took her vows. Ann was professed in October 1645. Their brothers John (1624-97) and George (1628-58) studied at the English College, St Omer, and became members of the Society of Jesus: see F. Blom and J. Blom, 'Keynes, John (1624-1697)', Oxford Dictionary of National Biography, Oxford University Press, 2004 [http://www.oxforddnb.com/view/article/15502]; and Thomas Seccombe, 'Keynes, George (1628-1658)', rev. Ruth Jordan, Oxford Dictionary of National Biography, Oxford University Press, 2004 [http://www.oxforddnb.com/view/article/15501].

${ }^{7}$ Anne and Mary were the daughters of Francis Harcourt and Dorothy Brett, and granddaughters of Alexander Brett (see note 6). Mary, professed in March 1651, assumed the religious name of Mary of the Angels; Anne, professed in August 1641, that of Anne of St Mary. Anne became sub-prioress in 1656 and superior in 1659, which she remained for 6 years (414-16, 498-99).
} 
However, looking back upon the "Religious course" that she had embarked upon, Cotton declared that since then "never any worldly thought hath occurr[e]d unto my mind, much less any inordinate affection caused me the least disturbance". Psychological tensions such as these are focused on time and again in the autobiographical portions of most Lives in the Collections. When read in the light of Margaret Cavendish's particular affection for Mary Cotton, one wonders whether the "special fortune then present", the "great temporal happiness and diverse exterior appearances", and the "worldly friendships" (509) could have alluded to the favors, material no less than intellectual, bestowed on her as a member of the Cavendish circle. Being singled out for membership of this circle was "a special fortune" in itself, one primarily reserved to the beau monde that frequented the Cavendish residence. The tokens of appreciation attaching to these friendships would have been appreciated by a young woman having several relatives in the convent but remaining an expatriate nonetheless. More than an afterthought, then, the Duchess's being "much taken" with Mary Cotton reads like a coded epitome of an episode in the nun's life, an epitome emphasizing the courageousness of her choice. The artistic sensibilities which Cotton was to evince -she composed "a most moving sweet Song of ye passion and another in honor of the immaculate conception of our $B^{\mathrm{d}}$ Lady" (513)- must have endeared her to the knowledgeable Duchess and her husband, who had also fallen under the spell of the musically talented Duarte daughters, Leonora, Francisca and Catharina. ${ }^{8}$ The frontispiece to Margaret's Natures Pictures captures the warm conviviality of an imaginary family gathering, the Duke and Duchess being depicted as presiding over the "Telling of Tales of pleasure \& of witt". When William Cavendish commended the "innocent" virtue of these stories, saying "A Vestal Nun may reade this, and avow it,/ And a Carthusian Confessor allow it." (b1r), he may have had in mind the future Carmelite nun staying in his house.

A telling indication as to the special treatment accorded Cotton is the specification that the Duchess "dressed her with her own hands" and, at the habit-taking ceremony, "led her in her self". In so doing, Margaret re-enacted a ritual commonly practiced at the Brussels archducal court of Clara Isabella Eugenia (1566-1633), sovereign of the Spanish Netherlands, many of whose Spanish and Flemish ladies-in-waiting took up a religious life under the

\footnotetext{
${ }^{8}$ Marika Keblusek, "Merchants' Homes and Collections as Cultural Entrepôts: The Case of Joachim de Wicquefort and Diego Duarte", English Studies, 92 (2011), 496-507. Margaret's ability to entertain life-long friendships is illustrated in the case of Elizabeth Topp (née Chaplain), who started out as the Duchess's 'waitingmaid', became the governess of her house and confidante, and "rose into the lower orders of the English aristocracy" (suggestion provided by journal's editors, with thanks). Topp also assisted the Duchess's first publications and acted as her intermediary with the London booksellers: see Whitaker, passim.
} 
Infanta's aegis. ${ }^{9}$ Most of them entered reformed orders such as the Discalced Carmelites or the Annunciads; and their monastic professions were invariably "heavily publicized spectacles". Sometimes Isabella herself "embroidered the precious robes of the little figure [of Christ]... carried in front of the young court lady during the procession to the convent where she was personally given" by the Archduchess. ${ }^{10}$ Her benevolence evidently extended to the Antwerp house as well, for she "often sent kind rememberances and shew'd great favour to young Ladys who passd by Brusselles to enter here [i.e. in Antwerp]". The Life of Elizabeth Worsley (1601-52), Theresa of Jesus Maria, younger sister to the first prioress, records that after her mother's death she was raised in a monastery and "at a fitt age" introduced to the Infanta's court. But her "solid judgment and pious Inclinations made her soon discover the vanity of all the grandeur of this world" (162). She therefore resolved to follow her sister's example and opted for the "happiness and security of a religious life" in the Carmel, "which being made known to the Infanta she with much pleasure contributed all that could make her enterance more splendid; she gave her a rich Cloathing Gown and was at the expence of all that Ceremony, sending several Ladys of her Court to be present at her Cloathing, the chief of which lead her in, and we suppose the Princess added to her fortune" (162-3). ${ }^{11}$

These are enlightening details, revealing as they do the nature of the sponsorship some of the novices enjoyed as well as the pomp accompanying their clothing. Mary Cotton was the sixty-fourth nun to be professed in the Carmel since its establishment in 1619 and one of the few on record to have benefited from this type of patronage. Her entry too would have been marked by a certain measure of splendor and her relationship with Margaret Cavendish must therefore have been a privileged one -as privileged as the Duchess's with the convent. It is unthinkable indeed that the latter, having resided in Antwerp since 1648, initially among "few English", was not alive to the importance of the Carmel, in mid-century the most conspicuous English presence in the city. ${ }^{12}$ It is equally improbable that she took on this high-profile role in Cotton's clothing (in both senses of the word), a role comparable to that of the Archduchess herself, if she had not enjoyed the confidence of the Carmelites, both as a prominent visitor and a former member of Queen Henrietta-Maria's Catholic court. The link connecting Margaret with the Antwerp house may have been no less a person than Lady Aletheia Howard

\footnotetext{
${ }^{9}$ Cordula van Wyhe, "Court and Convent: The Infanta Isabella and Her Franciscan Confessor Andrés de Soto", The Sixteenth Century Journal, 35 (2004), 411-45. Hereafter van Wyhe.

${ }^{10}$ van Wyhe, 425, 429

${ }^{11}$ She took her habit in May 1619, and was professed on 18 June 1620.

${ }^{12}$ The Rubens House and its adjacent properties bordered on the convent, in the Hopland area of the city: see Prosper Arents, De Bibliotheek van Pieter Pauwel Rubens: een reconstructie. Bewerking: Frans Baudouin, Lia Baudouin e.a. (Antwerpen, 2001), 72-75.
} 
(after 1582-1654), Countess of Arundel, whose grand style and expensive taste (she had acted in court masques as a young woman, had been painted by Rubens and had counted Anthony Van Dyck among her entourage) were challenged by all ceremonial occasions. Sent abroad by King Charles in 1641 with her husband Thomas Howard (1585-1646), 14 ${ }^{\text {th }}$ earl of Arundel, to accompany the queen's mother Marie de' Medici, she settled down in Amsterdam, where she maintained an impressive art collection and attracted a "circle of intellectuals". ${ }^{13}$ On at least two separate occasions Lady Arundel and her daughter-in-law Mary (1620/21-94), viscountess Stafford, ministered to the clothing and profession of English novices in Antwerp. In August 1644, when Margaret Mostyn (1625-79), Mother Margaret of Jesus, and her sister Elizabeth (1626/27-1700), Ursula of All Saints, took the habit, "they were dressed out as is customary for such a solemnity, and adorned with the costly jewels of Lady Catherine [i.e. Mary?] Howard and the Countess of Arundel, who attended...and led them into the monastery." 14 A year earlier, in August 1643, the same ladies had attended the bishop of Antwerp's examination, preparatory to her profession, of Anne Somerset (1613-51), the daughter of Henry Somerset (1576/77-1646), first marquess of Worcester, and Anne Russell (1579-1639). Lady Anne “[entered] into our Monastery with great Splendour, ceremony, Cloathed in black Velvett allmost all coverd with Pearls" (430) -like the Mostyn sisters no doubt decked out by Lady Arundel herself. ${ }^{15}$ We do not know how often she supplied her own garments and jewelry for such functions. But when she died in June 1654, the honor of introducing some novices to the Carmel may, as a matter of course, have passed on to Margaret Cavendish, whose noble stature, sense of spectacle, and family credentials were all up to the mark -her husband and Lady Arundel sharing the same grandparents, Sir William Cavendish (1508-57) and Elizabeth Talbot, née Hardwick (1527?-1608). ${ }^{16}$

\footnotetext{
${ }^{13}$ Michelle DiMeo, 'Howard, Aletheia , countess of Arundel, of Surrey, and of Norfolk, and suo jure Baroness Furnivall, Baroness Talbot, and Baroness Strange of Blackmere (d. 1654)', Oxford Dictionary of National Biography, Oxford University Press, Oct 2006; online edn, Jan 2008 [http://www.oxforddnb.com/view/article/94252].

${ }^{14}$ Edmund Bedingfield, The Life of Margaret Mostyn, Mother Margaret of Jesus, Religious of the Reformed Order of our Blessed Lady of Mount Carmel, 1625-1679 (London, 1878), 32. Hereafter Bedingfield. Both sisters were professed on 12 August 1645.

${ }^{15}$ Lady Anne asked the Catholic apologist Sir Tobie Matthew to act as her interpreter: see Antwerp Episcopal Archives, uncatalogued documents "Religiosae Theresianae Antverp. diversae litterae", no. 15. The first marquess gave his daughter a considerable dowry which played an important part in recruiting her for the Carmel, for "our first venerable Mother hearing of her having a Vocation promised Our B ${ }^{\mathrm{d}}$ Lady a Chappell in case she should settle here which Chaple was afterwards build [sic] in the garden."

${ }^{16}$ Sybil M. Jack, 'Cavendish, Sir William (1508-1557)', Oxford Dictionary of National Biography, Oxford University Press, 2004; online edn, Jan 2008 [http://www.oxforddnb.com/view/article/4943]; Elizabeth Goldring, 'Talbot, Elizabeth [Bess of Hardwick], countess of Shrewsbury (1527?-1608)', Oxford Dictionary of National Biography, Oxford University Press, 2004 [http://www.oxforddnb.com/view/article/26925].
} 
The new evidence corroborates the view that "[d]espite her decision not to convert to Catholicism, Cavendish's early life was informed by sympathies with the Catholic recusant community." 17 While Margaret refrained from commenting on organized religion, one of the features of the Roman faith that attracted her was that it "offered spectacle, costume, and theatre". ${ }^{18}$ It was around this time indeed, in The Worlds Olio (1655), that she reviewed the pros and cons of "A Monastical Life", with its "recreation[s] and pastime[s]" such as "Mass and Musick, and shewes, as at Christmas, Easter, our Lady day, \& on many days of the years." ${ }^{19}$ Cotton's habit-taking ceremony not only highlighted the exceptional care taken of her, symbolized by her eye-catching garments (see below), it would also have advertised the Duchess as an active contributor to the city's communal life as well as underscored the convent's unprejudiced reaching out to Antwerp's non-Catholic elite. Margaret's participation in the Carmel's widely publicized functions thus aptly illustrates Claire Walker's contention that "the religious houses in the Southern Netherlands...[provided] an external point of contact where their co-religionists (and Protestants) [our italics] might access the CounterReformation". 20

The hitherto unsuspected ties connecting Margaret Cavendish with the Antwerp Carmel raise the possibility that her comedy The Convent of Pleasure, first published in the 1668 collection Playes, Never Before Printed and assumed to have been composed after 1660, may have owed its origin to this particular context. ${ }^{21}$ In recent criticism, the setting of this separatist fantasy has been variously interpreted. Julie Crawford has argued that the convent of the title was based on three actual sites: St John's Abbey, Welbeck Abbey and the Convent

\footnotetext{
${ }^{17}$ Horacio Sierra, "Convents as Feminist Utopias: Margaret Cavendish's The Convent of Pleasure and the Potential of Closeted Dramas and Communities”, Women's Studies, 38 (2009), 649-69. Hereafter Sierra.

${ }^{18}$ Erna Kelly, "Playing with Religion: Convents, Cloisters, Martyrdom, and Vows", Early Modern Literary Studies, Special Issue, 14 (2004), 1-24 (9). Hereafter Kelly.

${ }^{19}$ The Worlds Olio. Written By the Right Honorable, the Lady Margaret Newcastle (London, 1655), 30.

${ }^{20}$ Claire Walker, "Priests, nuns, presses and prayers: the Southern Netherlands and the contours of English Catholicism", in Catholic communities in Protestant states. Britain and the Netherlands c.1570-1720, edited by Benjamin Kaplan, Bob Moore, Henk van Nierop and Judith Pollmann (Manchester, 2009), 139-55 (147).

${ }^{21}$ Plays, Never before Printed. Written by the Thrice Noble, Illustrious, and Excellent Princesse The Duchess of Newcastle (London, 1668). All in-text references to the play, by act, scene and line number, are to the edition in Three seventeenth-century plays on women and performance. The Wild-Goose Chase by John Fletcher (1621). The Bird in a Cage by James Shirley (1633). The Convent of Pleasure by Margaret Cavendish (1668), ed. Hero Chalmers, Julie Sanders and Sophie Tomlinson (Manchester, 2012). Hereafter The Convent. Alfred Harbage describes it as a closet play and assigns it to the period 1662-68: see Annals of English Drama 975-1700. Revised by S. Schoenbaum (London, 1964), 162-3.
} 
of Chaillot. The first was Margaret's family home; the second her home with her husband; the third the institution founded by Queen Henrietta-Maria in France in $1651 .^{22}$ Like the convent in the play, Chaillot was one "that did not disavow physical and material pleasure" for Henrietta-Maria donated to it much of her property, including "a range of furnishings much like those Lady Happy promises her novitiates". ${ }^{23}$ Lucy Worsley has ventured the (unsupported) suggestion that Margaret's "risqué" play may have been inspired by "the nunnery of St Mary's", which had been the site of the Duke's London residence since around $1630 .{ }^{24}$ Sierra, on the other hand, while pointing to the play's "[c] ontinental air", believes that its very "lack of an exact setting" allows Cavendish "to create an unspecified state of possibilities for her female characters. ${ }^{, 25}$ Erin Lang Bonin similarly looks upon the nunnery as "a separate, potentially oppositional space [...] a locus for fantasies, desires, and fears about female sexuality and power." 26 There is internal evidence, however, suggesting that in the conception of Lady Happy's convent Cavendish may have had an eye to the Carmelite foundation and its Antwerp context.

The third Gentleman's prediction that "this convent will never be dissolved by reason it is ennobled with the company of great princesses and glorified with a great fame" (3. 3. 3638) ostensibly applies to various religious houses in Flanders. The history of the Antwerp convent, however, was truly "glorified" by its association with nobility and royalty. These included the archduchess Isabella, as already noted; Philip William, duke of Neuburg (161590), who recruited several nuns from the Antwerp house to start a new Carmelite foundation in his territories in 1661; the exiled Charles II, his brothers James and Henry and his sister Mary, who visited the convent in $1658 ;^{27}$ and their cousin Louise-Hollandine of the Palatinate (1622-1709), who found refuge there prior to her conversion in $1657 .^{28}$

\footnotetext{
${ }^{22}$ "Convents and Pleasures: Margaret Cavendish and the Drama of Property”, Renaissance Drama, 32 (2003), 177-223. Hereafter Crawford.

${ }^{23}$ Crawford, 202-203.

${ }^{24}$ Cavalier. A Tale of Chivalry, Passion and Great Houses (London, 2007), 202-203. Were Lady Happy's "big and convenient" house, with its "gardens [...] walks [...] arbors [...] fountains, and the like", (2. 1. 53ff) and her itemization of its furnishings (2. 2. 9-56) modeled on the architecture of the Rubens House? For a summary description of the building, see Kathleen Jones, A Glorious Fame. The Life of Margaret Cavendish, Duchess of Newcastle, 1623-1673 (London, 1990), 71-2. That the Cavendishes were aware of the uniqueness of their magnificent home with its garden-in-the-city is proved by Gonzales Coques' pre-1660 aristocratic portrait of the couple against the background of the portico, loggia, trees and classical statues that were the eye-catching perquisites of the house: see Ursula Härting, "Lord William Cavendish und Margaret Cavendish im Rubensgarten in Antwerpen", Jahrbuch der Berliner Museen, 44 (2002), 15-28.

${ }^{25}$ Sierra, 649.

26“"Margaret Cavendish's Dramatic Utopias and the Politics of Gender", Studies in English Literature, 40 (2000), 339-54 (347).

${ }^{27}$ When Charles II and his brothers "came into the Monastery the Duke of York came to the King and told him if he had a mind to see a pretty woman he must go to the Infirmary, which he did, where dear Sister Tecla was"
} 
Yet no personality can have graced the Carmel with her presence more than Queen Christina of Sweden, who after her abdication in June 1654 made the city of Antwerp her home from 5 August 1654 until 23 December 1655. Immediately after her arrival, Christina began a long series of courtesy calls to religious institutions in Flanders, giving pride of place to the Antwerp Discalced Carmelites, which she visited on 7 August. ${ }^{29}$ What with her reputation as a skilled horsewoman, an avid playgoer and, above all, a prodigal hostess, she soon became a major tourist attraction and the talk of the town. As one observer of the social scene put it: "The throngs of the Cityzens were for some days so great, that they could hardly passe up and downe in the streets, that were near to her Court." ${ }^{30}$ Considering how many envoys, ambassadors and travelers flocked to pay their respects, it is very likely that her contacts with the Antwerp élite would have encompassed the Cavendish circle, although admittedly no meeting between them has been recorded. Margaret Cavendish would have been fascinated by Christina's intellectual accomplishments, her extravagant behavior and her position as a Protestant monarch desiring to adopt the Catholic faith, having quite literally come "from a splendid court to a retired convent" (3.1.1-2). The queen, indeed, provided more than a hint for the character of the Princess, epitomized by Madam Mediator as a "brave woman truly, of a masculine presence" (2. 3. 9-10). Contributing to the homoerotic ambiguities in The Convent, the request of the Prince(ss) to "accoutre" her(him)self "in masculine habits" (3.1.13) and her/his later appearance in "a man's dancing outfit" (5.1) are consistent with Christina's incognito arrival in Antwerp in a man's habit, a fact recorded by contemporary newsletters, and with the androgynous persona she liked to project. $^{31}$ In addition, the play's faintly outlined affairs of state -the Prince's misgivings about abandoning

(417). Tecla of Saint-Paul, who had made her profession in 1641, aged 17, was admired for her "most Angelicall Innocence... agreeable sweet temper" and a "lovely and beautiful" person.

${ }^{28}$ Claire Walker, "Loyal and Dutiful Subjects: English Nuns and Stuart Politics", in Women and Politics in Early Modern England, 1450-1700, ed. James Daybell (London, 2004), 228-42.

${ }^{29}$ For a calendar of her stay in the Spanish Netherlands, see Diederik Lanoye, Christina van Zweden. Koningin op het schaakbord Europa 1626-1689 (Leuven, 2001), 171-82. Hereafter Lanoye.

${ }^{30}$ Galeazzo Gualdo Priorato, The History of the Sacred and Royal Majesty of Christina Alessandra Queen of Swedland. With the Reasons of her late Conversion to the Roman Catholique Religion, trsl. John Burbery (London, 1658), 71. Priorato records that on 17 August the Queen left for Brussels, where she visited "the Monastery, of the Carmelite discalceat Nunns, of the order of St. Teresa" as well as other convents (78).

${ }^{31}$ Whitaker notes that Christina's "scenario" of "female power and romance" as scripted during her stay at Antwerp coincided with the Duchess's nascent interest in stories about "women and the ambitious undertakings that might be possible in their lives" (182). Susan James also connects the image of the "heroic female warrior wearing male, martial dress" in Cavendish's The Blazing World (1666) with Queen Christina, who "visited Antwerp while Cavendish was living there": see Margaret Cavendish, Duchess of Newcastle. Political Writings, ed. Susan James (Cambridge, 2003), 16. But neither critic establishes a link with The Convent. For a contemporary testimony on Christina's protean appearance, see: The Faithful Scout. Number 192: From Friday August the $11^{\text {th }}$ to Friday August the 18 $8^{\text {th }}$ 1654: "She is now arrived at Antwerp, in mans Apparel, coming there incognito with a small company, her Train arriving there the next day, at which time she was drest in womens Apparel..." (1518). 
a kingdom (4. 1. 162-165) greatly respected as a naval power (4. 1. 195-206), the ambassador's urgent plea for the Prince to return home, and the latter's intention to marry Lady Happy (5. 1. 12-22)- echo aspects of Christina's position as a resident of the Spanish Netherlands. Her suspected marriage plans, with Philip IV of Spain, archduke LeopoldWilhelm, and King Charles II being named as possible partners; the role she could play in the matter of Sweden's re-armament aimed at regaining control of the Baltic; and the attempt of count Klas Tott, sent by the Swedish senate in November 1654 to recall her, allegedly in order to reclaim her from her expensive ways of living and "Romish proclivities" -all of these were the object of much speculation in the months prior to Christina's secret conversion at Brussels on Christmas Eve $1654 .^{32}$

An underlying awareness of the Carmel's eventful history also seems to inform Lady Happy's banishment of "the masculine company for ever" (2. 1. 79). More than being a dramatic device, her convent's strict isolation strangely mimics the obstacles that the Carmel's foundresses, Mary Lovell and especially Ann Worsley, had to overcome preventing the Provincial of the Carmelites from encroaching on the Antwerp institution's privileges. Only by dogged resistance indeed did the first-generation nuns safeguard the foundational principles laid down by St Teresa. ${ }^{33}$ The rule that Lady Happy's convent is off-limits to men could be read as a fictional re-enactment of St Teresa's rule guaranteeing the Carmel a complete independence from the authority of their male counterparts in the Order. Admittedly, neither in the play nor in the real-life convent is/was this course indefinitely maintained: Lady Happy in act 5 gives her hand in marriage to the "great foreign" Prince (2. 3. 6) in the same way that the Carmel was soon "settled under the Obedience" of the bishop of Antwerp (Collections, 95). For decades echoes of this struggle kept resounding in a variety of documents relating to the convent's early history -private letters, printed constitutions, papal bulls, and bishops' reports. If she had any knowledge of the Carmel's history, Cavendish may have been privy to this local episode in the nuns' opposition against the "authoritarian intrusions" that had plagued the Order since the days of St Teresa herself. ${ }^{34}$

\footnotetext{
${ }^{32}$ I. A. Taylor, Christina of Sweden (London, [1909]), chapter X, 125. See also Lanoye, passim.

${ }^{33}$ For a summary, see Dodd's Church History of England From the Commencement of the Sixteenth Century to the Revolution in 1688. With Notes, Additions, and a Continuation, ed. M. A. Tierney, vol. 4 (London, 1841), 112-16. Alluding to the Spartan regime in Carmelite houses, Cavendish has Lady Happy question the need for "men and women [to] wear coarse linen or rough woollen, or to flay their skin with hair-cloth, or to eat or saw through their flesh with cords" (1.2.45-47), as a result of which "the senses are dulled with abstinency, the body weakened with fasting, the spirits tired with watching, the life made uneasy with pain" (ib., 66-68) --an eerily accurate epitome of countless Lives in the Collections.

${ }^{34}$ See http://www.ocd.pcn.net/nuns/n4 en.htm. The Antwerp monastery could trace its lineage straight back to St Teresa through the Spanish nuns by whom Anne Worsley, the first English Teresian, had been 'educated': see Bedingfield, 30-31.
} 
Paradoxically, the strongest piece of evidence connecting Cavendish's play with the Carmel is the slightly mystifying detail in Cotton's biography that she was led in dressed "like a Nimph", apparently an indecorous habit. Cavendish's interest in fanciful clothing, it must be remembered, contributed a great deal to her reputation for quirkiness. ${ }^{35}$ In her life story included in Natures Pictures, she testified to taking

...great delight in attiring, fine dressing and fashions, especially such fashions as I did invent my self, not taking that pleasure in such fashions as was invented by others: also I did dislike any should follow my fashions, for I always took delight in a singularity, even in acoutrements of habits, but whatsoever I was addicted to, either in fashions of Cloths, contemplation of Thoughts, actions of Life, they were Lawfull, Honest, Honorable and Modest. ${ }^{36}$

"Modest" or not, Mary Cotton's nymph's dress would be no more extraordinary than Margaret Mostyn's jewels or Anne Somerset's black velvet if it were not for the appearance in the pastoral scenes of The Convent of a number of "water-nymph" -the only occurrence of such characters in the Duchess's dramatic works. Is this a mere fortuity or was Cotton's garb the one that had been designed for a performance of The Convent at the Rubens House? Had the musically gifted Cotton herself played the (vocal) part of a sea-nymph in the play, and was this one of those "exteriour apparences of a most absolute affection unto my self" that she wistfully looked back upon as a nun? In addition to the King of Navarre's "little academe" in Love's Labour's Lost (I, 1, 13), was it Cotton's religious destination that inspired Cavendish's idea of an all-female place of retreat $?^{37}$ None of these questions can be definitively answered except that the recorded existence of a nymph's garment, devised by the fashion icon Cavendish herself, makes a pre-1660 composition date and performance of The Convent, or some early version of it, conceivable.

This possibility is not contradicted by what we know of cultural life at the Cavendish home. Pastorals were part of the theatricals given at the Rubens House, as is attested to by a dramatic fragment included in William Cavendish's literary legacy, "A Prologe thatt shoulde have been spoken before an Intended [and so far unidentified] Pastorall att Antwerpe", and by the record of an entertainment, written by him and the musician Nicholas Lanier, in honour of

\footnotetext{
${ }^{35}$ On 14 April 1653, Dorothy Osborne reported that the Duchess's latest book of poems was "ten times more Extravagant then her dresse": see The Letters of Dorothy Osborne to William Temple, ed. G.C. Moore Smith (repr. Oxford, 1968), 37.

${ }^{36}$ Natures Pictures, 387. Animated by such sartorial "pleasure", Lady Happy makes it one of the rules of her convent that "[c]hange of garments are also provided, of the newest fashions for every season, and rich trimming so as we may be accoutred properly and according to our pastimes." (2. 2. 52-54)

${ }^{37}$ On The Convent of Pleasure as a Shakespearean inspired "parody" of "male-only retreats of learning" and a coming together of "the symbolic rejection of mere appetite" and "the concrete culmination of sense", see Brandie R. Siegfried, "Dining at the Table of Sense: Shakespeare, Cavendish, and The Convent of Pleasure”, in Cavendish and Shakespeare, Interconnections, ed. Katherine Romack and James Fitzmaurice (Aldershot, 2006), 63-83 (71, 74). Hereafter Siegfried.
} 
the King and staged in February $1658 .^{38}$ The Convent not only gave dramatic expression to the concept of an ideal feminine world, it allowed the Duchess to populate this world with characters attired in her own fanciful creations -shepherds and shepherdesses, the Princess "dressed as Neptune", Lady Happy "as a sea-goddess", and both of them "as bridegroom and bride" (4. 1. 27, 194; 5. 3. 1). In the masques occupying most of act 4, and performed before a convent audience, Lady Happy's ladies appear "dressed as water-nymphs" singing a song in celebration of "our sea's king" (4. 1. 194, 280). ${ }^{39}$ Aside from specifying that they are wearing "sea-green habits" (4. 1. 281), the text offers no indications about their appearance. But Margaret's plays drew upon the key influence in her husband's entertainments, Ben Jonson's court masques, with their stage designs by Inigo Jones. ${ }^{40}$ Her nymphs, then, were probably conceived after the manner of Jones's richly costumed characters, such as those in Jonson's Masque of Blacknesse (1605) and Chloridia (1631). ${ }^{41}$ Such attire, at any rate, would also have suited the decorum required at Cotton's entry. The view therefore that "Cavendish's emphasis [i.e. in her play] on a proliferation of varied sensual delights...[differentiates] her convent from real convents" should be qualified in view of the Duchess's 'theatrical' transformation of Mary Cotton into a nymph, a figure symbolically bridging the gap between the Rubens House world of stage entertainments and the Carmel world of serious religious ceremony. ${ }^{42}$ If Lady Happy's words, "But why may not I love a woman with the same affection I could a man?" (4. 1. 3-4), intimate the possibility of a homoerotic relationship between her and the Princess, they apply just as well to Margaret's infatuation with her protégée. "Much taken" with Cotton "as being extream pretty", the Duchess, Pygmalion-like, may have fallen in love with her own creature. ${ }^{43}$

\footnotetext{
${ }^{38}$ Dramatic Works by William Cavendish, ed. Lynn Hulse. The Malone Society Reprints, vol. 158 (London, 1996), xv, 45-47.

${ }^{39}$ In addition to counselors, magistrates, and military leaders, the government of the Princess's well-ordered state, it may be noted, is supported by religious people, "Neptune's priests which pray/ And preach when is a holy day" (4. 1. 272-73; our italics).

${ }^{40}$ James Knowles, “'We've lost, should we lose too our harmless mirth?'. Cavendish's Antwerp Entertainments", in Royalist Refugees. William and Margaret Cavendish in the Rubens House 1648-1660, ed. Ben Van Beneden and Nora de Poorter (Antwerp, 2006), 70-77; 71; The Convent, Introduction, 41.

${ }^{41}$ Percy Simpson and C. F. Bell, ed., Designs by Inigo Jones for Masques \& Plays at Court. A Descriptive Catalogue of Drawings for Scenery and Costumes mainly in the Collection of His Grace the Duke of Devonshire, K.G. (1924; reprint New York, 1966), Plates I, XVII, XVIII.

${ }^{42}$ Kelly, 6. Pointing to the description of a profession ceremony in Aphra Behn's Love Letters between a Nobleman and his Sister, Sara McMaster remarks, “...in Flanders there probably were convents which resembled the Convent of Pleasure, established to cater to the comfort and entertainment of a wealthy welleducated elite": see "Concocting the world's olio: Margaret Cavendish and continental influence", Early Modern Literary Studies. Special issue 14 (2004), 1-34 (29).

${ }^{43}$ Siegfried calls attention to Cavendish's use of cross-dressing (in the Shakespearean tradition) as a way of validating masculinity and femininity as "both acceptable modes of social discourse within the convent" (79).
} 
The evidence contained in the Antwerp Collections allows us to catch a glimpse of a relatively neglected side of Margaret Cavendish's social life in the 1650s. In addition to local and foreign nobility and a number of intellectual friends and correspondents, she may have maintained good relations with the Carmelite convent, a space which in The Convent and elsewhere she idealized as offering women an alternative to a wedded life of ignorance and drudgery. Echoing the action in The Convent, Lady Perfection and Lord Melancholy, the protagonists in The Religious (1662), after the annulment of their marriage contract a new one, agreeing to enter the "Religious Order of Chastity" and spend their lives "incloystered" in a nunnery of their own making $(544,554) .{ }^{44}$ Until further evidence emerges about the exact nature of the English convent's cultural impact, we may not be in a position to determine the artistic, literary or other attractions it held in store for Margaret Cavendish. ${ }^{45}$ But it seems clear that the specific Antwerp context of the 1650s -the Carmel itself, Mary Cotton, and the figure of Queen Christina- supplied some of the ingredients that went into the making of The Convent of Pleasure, to which a pre-1660 composition date may plausibly be assigned.

\section{Ghent University}

\footnotetext{
${ }^{44}$ Playes Written by the Thrice Noble, Illustrious and Excellent Princess, the Lady Marchioness of Newcastle (London, 1662).

${ }^{45}$ The editors of Cavendish's play have suggested that it "may also draw on a tradition of female recreation in convent theatricals": see The Convent, Introduction, 38. While there are scattered references to dramatic entertainments in Collections, the existence of theatrical activities in women's religious foundations in the Spanish Netherlands, in general, or in the Antwerp foundation, specifically, has remained unexplored.
} 
